\title{
Prevalence of asymptomatic bacteriuria among pregnant women: a cross- sectional study in Harare, Zimbabwe
}

\author{
Judith Musona-Rukweza', Muchabayiwa Francis Gidiri², Pasipanodya Nziramasanga³, \\ Clara Haruzivishe', Babill Stray-Pedersen ${ }^{4}$ \\ ${ }^{\prime}$ Department of Nursing Science, College of Health Sciences, University of Zimbabwe, Harare, Zimbabwe \\ ${ }^{2}$ Department of Obstetrics and Gynecology, University of Zimbabwe, Harare, Zimbabwe \\ ${ }^{3}$ Department of Medical Microbiology, University of Zimbabwe, Harare, Zimbabwe \\ ${ }^{4}$ Institute of Clinical Medicine, University of Oslo, Oslo, Norway
}

\begin{abstract}
Objective: The aim of this study was to estimate prevalence of asymptomatic bacteriuria among pregnant women registering for antenatal care.

Methods: A cross sectional study was conducted at 4 purposively selected Harare Municipality primary care clinics. A total of 240 pregnant women asymptomatic for urinary tract infection, registering for antenatal care at 6 and 22 weeks gestation were included. Those unaware of their last menstrual period date, clinically unwell and those who declined to sign a consent form were excluded in this study. Participants were instructed to provide 20 mililiters of midstream urine samples in clean specimen bottles. All samples were screened for asymptomatic bacteriuria using Griess nitrite test. Samples that changed color from clear to purple were considered positive for asymptomatic bacteriuria. Positive samples were further sent for culture and sensitivity. A colony count of 103 similar bacterial species per mililiter of urine was considered significant for asymptomatic bacteriuria.

Results: The prevalence of asymptomatic bacteriuria was $14.2 \%$ (95\% CI, $10.28 \%$ to $19.22 \%$ ). Participants' mean age was 25.6, mean gestation 17.3 weeks and majority $(70.8 \%)$ were unemployed. Coagulase negative staphylococcus was the most popular (29.4\%) bacteria isolated, followed by Escherichia coli (23.5\%). Most bacteria were sensitive to ciprofloxacin which was popularly used to treat the disease. Conclusion: Prevalence of asymptomatic bacteriuria among pregnant women is high. Screening and treatment of the disease in pregnancy is therefore important. This could prevent pregnancy complications and adverse birth outcomes associated with it.
\end{abstract}

Keywords: Asymptomatic bacteriuria, prevalence, screening, contamination, pregnancy.
Özet: Gebelerde asemptomatik bakteriüri prevalansı: Harare, Zimbabve'de kesitsel çalışma

Amaç: Bu çalışmanın amacı, antenatal bakım için başvuran gebelerde asemptomatik bakteriüri prevalansını hesaplamaktır.

Yöntem: Harare şehrinde özel olarak seçilen 4 birinci basamak klinikte kesitsel bir çalışma gerçekleştirildi. Çalışmaya, idrar yolu enfeksiyonu yönünden asemptomatik olan ve gebeliklerinin 6.-22. haftalarında antenatal bakım için başvuran 240 gebe dahil edildi. Son adet dönemini bilmeyenler, klinik olarak hasta olanlar ve aydınlatılmış onam imzalamayı reddeden gebeler çalışmadan çıkarıldı. Olgulardan, temiz örnek kaplarında $20 \mathrm{ml}$ orta akım idrar örnekleri getirmeleri istendi. Tüm örnekler, Griess nitrat testi kullanılarak asemptomatik bakteriüri yönünden incelendi. Berrak renkten mor renge dönüşen örneklerin asemptomatik bakteriüri yönünden pozitif olduğu düşünüldü. Pozitif çıkan örnekler, kültür ve duyarlılık kontrolü için gönderildi. İdrarda mililitre başına 103 benzer bakteriyel tür koloni sayımı, asemptomatik bakteriüri için anlamlı kabul edildi.

Bulgular: Asemptomatik bakteriüri prevalansı \%14.2 idi (\%95 güven aralığı, \%10.28-19.22). Olguların ortalama yaşı 25.6, ortalama gebelik haftası 17.3 olup, çoğunluğu (\%70.8) işsizdi. Koagülaz negatif stafilokoklar, en yaygin izole bakteri (\%29.4) olup, ikinci sırada Escherichia coli (\%23.5) yer almaktaydı. Çoğu bakteriler, hastalığın tedavisinde yaygın şekilde kullanılan siprofloksazine karşı duyarliydi.

Sonuç: Gebelerde asemptomatik bakteriüri prevalansı yüksektir. Bu nedenle gebelik sırasında hastalığın taranması ve tedavi edilmesi önemlidir. Bu şekilde, gebelik komplikasyonları ve ilişkili advers doğum sonuçları önlenebilir.

Anahtar sözcükler: Asemptomatik bakteriüri, gebelik, kontaminasyon, prevalans, tarama.
Correspondence: Judith Musona-Rukweza. Department of Nursing Science, College of Health Sciences, University of Zimbabwe, Harare, Zimbabwe. e-mail: rukwezajudith@gmail.com Received: September 30, 2017; Accepted: December 7, 2017

Please cite this article as: Musona-Rukweza J, Gidiri MF, Nziramasanga P, Haruzivishe C,

Stray-Pedersen B. Prevalence of asymptomatic bacteriuria among pregnant women: a cross- sectional study in Harare, Zimbabwe. Perinatal Journal 2017;25(3):133-138.

๑)2017 Perinatal Medicine Foundation
Available online at: www.perinataljournal.com/20170253009 doi: $10.2399 /$ prn.17.0253009 QR (Quick Response) Code:

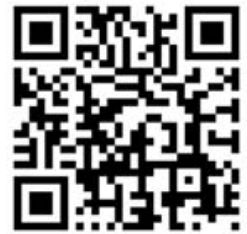




\section{Introduction}

Asymptomatic bacteriuria (ASB) is among most common infections in pregnancy with a considerable contribution to pregnancy complications and adverse birth outcomes. ${ }^{[1]} \mathrm{ASB}$ is a type of urinary tract infection that is diagnosed by urine culture test. The yielding of significant $[>105$ colony forming units per milliliter $(\mathrm{cfu} / \mathrm{ml})]$ amount of similar single bacterial species by culture test of clean catch urine from an individual without history of urinary tract infection symptoms confirms diagnosis of ASB. ${ }^{[2,3]}$

ASB prevalence among pregnant women generally ranges from $2 \%$ to $10 \%{ }^{[4,5]}$ When ASB occurs in pregnancy it raises great concern if left undetected and untreated. More than $30 \%$ of cases progress fast to pyelonephritis, an acute urinary tract infection. ${ }^{[6,7]}$ Pyelonephritis is associated with several pregnancy complications and adverse birth outcomes including hypertension, foetal mortality, endometritis, anaemia, amnionitis and renal insufficiency. ${ }^{[2]}$ Pyelonephritis often needs hospital admission and may lead to sepsis. ${ }^{[8]}$ ASB and pyelonephritis are independently associated with preterm birth and low birth weight. ${ }^{[9,6]}$ Meanwhile preterm birth and low birth weight are the leading causes of neonatal mortality and morbidity. ${ }^{[10]}$

The increased progression of asymptomatic bacteriuria is enhanced by the physiological and anatomical changes that occur in pregnancy. ${ }^{[1]}$ Plasma volume increases during pregnancy resulting in a decrease in urine concentration. ${ }^{[6]}$ Glycosuria is also noted in approximately $70 \%$ of pregnant women which promote multiplication of bacteria in urine. ${ }^{[4]}$ These often lead to diminished peristalsis and dilation of pelvis and ureters leading to decreased bladder tone. The end result is obstruction in the urinary tract. ${ }^{[12]}$

Gram negative bacteria are predominantly responsible for ASB. ${ }^{[1]}$ The commonly isolated bacterial species in ASB include Escherichia coli, Klebsiella pneumoniae, Proteus species, Staphylococcus aureus, Group B streptococcus and Pseudomonas. ${ }^{[4,13]}$

Screening and treating ASB in pregnancy is recommended during antenatal care especially at initial registration. ${ }^{[14]}$ Culture is the gold standard and recommended test for diagnosing ASB. ${ }^{[12]}$ The challenge with culture test is that it is expensive and unavailable in most low resource settings. ${ }^{[12]}$ This could be a limiting factor as screening for ASB is not being done in several low resource settings.

There is little understanding about ASB in pregnancy and its burden in Zimbabwe. Data on prevalence of ASB in pregnancy is unavailable in for Zimbabwe. ASB is also not being screened during antenatal care. Pregnant women are only empirically treated when they already are presenting with urinary tract symptoms. Meanwhile this problem could be common among pregnant women and contributing to pregnancy complications and adverse birth outcomes. The aim of this study was to estimate prevalence of asymptomatic bacteriuria among pregnant women registering for antenatal care at selected municipality clinics in Harare.

\section{Methods}

A cross sectional study design was used to estimate prevalence of ASB as detected from baseline status among pregnant women recruited at 4 purposively selected Harare Municipality clinics. This study was conducted as part of a main study. Simple random sampling method was used to recruit participants. Recruitment was done for 18 weeks between 23 February and 27 June 2017. The Dobson formula $\mathrm{n}=$ $(\mathrm{Z} \alpha+\mathrm{Z} \beta) 2[\mathrm{P} 1(1-\mathrm{P} 1)+\mathrm{P} 2(1-\mathrm{P} 2)](\mathrm{P} 1-\mathrm{P} 2) 2$ was used to calculate sample size. After factoring in an attrition of $25 \%$, at least 198 participants were required.

All pregnant women reporting at the selected sites for registration for antenatal care at gestation between 6 and 22 weeks, who remembered their first date of last menstrual period, voluntarily signed their consent form and were asymptomatic for bacteriuria were included in this study. All women who failed to remember her last menstrual period date, had a history of chronic renal disease or urinary tract structural deformity, urinary tract symptoms, and declined to sign a consent form were excluded in this study.

Participant consent was obtained before participant was enrolled in this study. There was no any form of penalty to an individual who declined to sign consent and who withdrew from the study. A serial number was used for identification for confidentiality and anonymity. Ethical approval for conduction of this study was obtained from the Medical Research Council of Zimbabwe. 
Demographic data and obstetric history was obtained using a structured questionnaire. Instructions on collection and submission of required urine specimens were repeatedly given to give emphasis on obtaining clean catch midstream urine and avoiding contamination. A hand sanitizer was rubbed on both hands to reduce bacteria that could contaminate urine during collection. Cleaning of external genitalia was discouraged as it was considered possible risk for contamination. A surgically clean and labeled specimen bottle was provided. All participants were asked to provide 10 to 20 milliliters of midstream clean catch urine.

Once submitted, the samples were screened for ASB using the Griess nitrite test (Gnt) in a designated room within 30 minutes. Gnt involved adding singly, 50 microliters ( $\mu \mathrm{l})$ of 2 Griess reagents, sulphanilamide and $\mathrm{N}$-1-naphthylethylenediamine dehydroxide, in a space of 5 minutes. The Gnt detects nitrite in the sample, which assumes that its presence associated with existence of nitrate reducing bacteria in the urine tract. Samples changed color from clear to purple was considered positive for ASB. The Gnt positive samples were stored in a cooler box. These were transported to a Medical Microbiology Laboratory of the University of Zimbabwe for culture test. All samples that remained clear after Gnt were considered negative for ASB and were discarded.

In the laboratory non- centrifuged urine samples were streaked on culture medium, 'blood and cystine lactose electrolyte deficient (CLED) agar'. Blood agar provides nutrients that support growth of bacteria often difficult to grow. CLED agar supports growth of all urinary pathogens and gives good colonial differentiation and clear diagnostic characteristics. The samples were incubated under $37^{\circ} \mathrm{C}$ over 24 hours. Samples that had growth of $>103 \mathrm{cfu} / \mathrm{ml}$ of the same bacterial species were considered significant for ASB. Samples that had mixed and insignificant growth $(<103 \mathrm{cfu} / \mathrm{ml})$ were considered contaminated. Samples that had mixed growth with dominant significant bacterial growth, the dominant was considered significant for ASB. The isolated bacterial species went through identification process and antibiotic sensitivity was conducted to establish the effective and resistant antibiotic drug list. ASB prevalence was estimated from culture test results. The women with a positive sample were contacted to visit clinic for results and prescription. Local nurses and doctors were involved in prescribing of safe and effective antibiotics to use in pregnancy referring to the provided drug list on the result form.

Data was analyzed using Statistical Package for Social Sciences Statistics version 20 (SPSS Inc., Chicago, IL, USA) as well as STATA version 13 (Stata Corp., College Station, TX, USA). Confidence interval, frequencies and percentages were used in data analysis.

\section{Results}

A total of 240 pregnant women participated in this study. There was no missing data for the characteristics and variables studied in this study. Participants' ages ranged from 15 to 41 years, with mean age 25.5 years (SD + 6.26). A total of $46(19.2 \%)$ were teenagers (15 to 19 years). Minimum and maximum gestation at recruitment was 6.2 and 22 weeks (17.3 mean, SD + 3.54). A total 160 $(66.7 \%)$ had a gestation below 16 weeks with majority [91 (37.9\%)] at 6.2 and 12 weeks. Majority [89 (37.1\%)] of the women were nulliparous. Only 3 (1.3\%) participants had a history of 5 previous pregnancies. All (100\%) participants had primary education with $29(12.1 \%)$ who did not proceed whilst majority [192 $(80 \%)]$ proceeded to secondary education. Most $[170(70.8 \%)]$ participants were unemployed whereas $70(29.2 \%)$ were employed. At household level, 112 (46.8\%) participants were surviving on a monthly income of less than 200 US dollars.

All (100\%) samples were screened for ASB by Gnt. A total of 50 samples $(20.8 \%)$ out of 240 were considered positive with Gnt as shown on Table 1. The positive samples were further tested by culture. Thirty four samples had significant growth of bacterial species. Six $(12 \%)$ samples had no bacterial growth, 2 (4\%) were contaminated, $8(16 \%)$ had mixed growth of insignificant bacterial levels, as shown on Table 2. Prevalence of ASB in this study was therefore $14.2 \%$ (95\% CI, 10.28\% to $19.22 \%)$. Teenagers had highest ASB cases [10 (29.4\%)]. Majority of the unemployed [27 (79.4\%)] women had ASB. ASB cases were highest among women

Table 1. Griess nitrite test results

\begin{tabular}{llcc}
\multicolumn{2}{l}{ Griess result } & Frequency & Percent (\%) \\
\cline { 3 - 4 } Valid & Negative & 190 & 79.2 \\
& Positive & 50 & 20.8 \\
& Total & 240 & 100.0 \\
\hline
\end{tabular}


who were pregnant for the first time [15 (44.1\%)] followed by those with history of 3 or more pregnancies [14 (41.2\%)]. Most cases [27 (79.4\%)] of ASB were among women with gestation between 16 and 22 weeks.

Ten bacterial species were isolated from culture test. Coagulase negative staphylococcus (CoNS) was the most popular bacteria isolated [10 (29.4\%)], followed by Escherichia coli (E. coli) [8 (23.5\%)]. The other bacterial species included Staphylococcus aureus, Klebsiella pneumoniae, Bacillus, Providencia, Shigella and Salmonella. Ciprofloxacin was popularly [23 (67.6\%)] used to treat those with significant ASB, followed by gentamycin [4 (11.8\%)]. Nitrofurantoin was used on 1 participant only. The other antimicrobials used included ceftriaxone, chloramphenicol and erythromycin.

\section{Discussion}

ASB is a common infection among pregnant women. If left untreated, the disease may lead to pregnancy complications and adverse birth outcomes including pyelonephritis, preterm birth and low birth weight. ${ }^{[6]} \mathrm{A}$ total of 240 pregnant women participated in this study. The sample size was adequate to give an insight to disease burden in the setting. An almost similar sample size (250) was used in a separate study. ${ }^{[15]}$ Demographic characteristics and obstetric history including age, marital status, sex, socioeconomic status, parity and gestation have an influence on prevalence of ASB ${ }^{[16]}$ Majority of the cases with significant bacteriuria were among teenagers registering at gestation between 16 and 22 weeks. A considerable number of women [27 (79.4\%)] diagnosed with ASB were unemployed and virtually earning nothing at all.

Use of a cost effective screening test for ASB is recommended as it reduces the burden of high cost of culture. ${ }^{[15]}$ There are various screening tests that could be used. In this study the Gnt was used and proved to be a reliable screening test when compared to culture, because all negatives were confirmed negative and all positive samples were truly positive. ${ }^{[17]} \mathrm{A}$ high sensitivity (92.3\%) and specificity (99\%) was reported in another study conducted in India where Griess nitrite test was used to screen for ASB in pregnancy. ${ }^{[12]}$ Screening of ASB during pregnancy is universally recommended at 12 to 16 weeks. ${ }^{[16]}$ However, there is no universal consensus as to which screening test to be used.
Table 2. Culture test results for asymptomatic bacteriuria.

\begin{tabular}{lcc} 
Culture results & Frequency & Percent (\%) \\
Negative & 6 & 12 \\
Positive & 34 & 68 \\
Contaminated & 2 & 4 \\
Mixed growth & 8 & 16 \\
Total & 50 & 100.0 \\
\hline
\end{tabular}

Currently detection and diagnosis of ASB relies on culture test. ${ }^{[16]}$ Culture test is the recommended and gold standard test for diagnosis of ASB.$^{[15]}$ Diagnosis of ASB in this study was made from significant growth from a single culture test. In this study a culture growth of 103 colony forming units per milliliter of urine $(\mathrm{cfu} / \mathrm{ml})$ of clean catch urine sample was considered significant for ASB. This count could mean an early phase of urinary tract infection, unlike $102 \mathrm{cfu} / \mathrm{ml}$ which is often related to contamination of sample. Historically $105 \mathrm{cfu} / \mathrm{ml}$ was agreed at as a significant result but the level has been cut off even down to $103 \mathrm{cfu} / \mathrm{ml}$, although this has not been translated into practice. ${ }^{[18]}$ Colony count of 103 was used in another study as a significant level for bacteriuria and obtained a prevalence of $21 \% .{ }^{[19]}$ There has so far been no screening test for ASB that has proved to be as reliable as the culture test. ${ }^{[9]}$ However, the test has its own weaknesses of inadequate sensitivity and specificity. ${ }^{[16]}$

The prevalence of ASB differs from one setting to another but it is generally noted to be between $2 \%$ and $10 \%$ in the world. ${ }^{[6]}$ It is also reported to be ranging from $1.9 \%$ to $15{ }^{[20]}$ Prevalence of ASB in this study was considerable at $14.2 \%$ (95\% CI, $10.28 \%$ to $19.22 \%$ ). The prevalence was comparable to that of Iran reported in a systematic review which was generally at $13 \%$ (95\% CI, 9\% to $17 \%) .{ }^{[20]}$ In a study conducted in Egypt, ASB prevalence was 10\% (95\% CI 5.93\% to $15.53 \%){ }^{[21]}$ Screening method selected, definition of ASB used and socioeconomic status of studied population have influence on prevalence obtained. ${ }^{[22]}$ However, the prevalence obtained in this study could help to provide a clue on ASB disease burden in our setting. It also provides justification to the need to prioritise screening for ASB during antenatal care as the prevalence is largely above $2 \% .{ }^{[10]}$ However, new cases could have been absorbed in this prevalence as it was done over a 4 month period. 
Generally E. coli is reported to be the most common bacteria responsible for $70 \%$ to $90 \%$ of $\mathrm{ASB} .{ }^{[21,16]} \mathrm{CoNS}$ was the most popular (29.4\%) bacterial species responsible for ASB in this study, followed by E. coli (23.5\%). CoNS, also classified as Staphylococcus saprophyticus, is responsible for bacteriuria and was once reported to be 2 nd leading cause of urinary tract infection. ${ }^{[23]}$ In a separate study, there were 31 (14\%) cases of CoNS out of 219 women with bacteriuria. ${ }^{[2]}$ From a study conducted in Nigeria, Staphylococcus aureus was the most common (41.3\%) pathogen, followed by Klebsiella (33.3\%) then E. coli $(11.1 \%){ }^{[19]}$ E. coli was the most popular (77.27\%) bacteria responsible for ASB in another study. ${ }^{[25]}$ Types and popularity of bacterial species responsible for ASB may therefore be different from one setting to another. However, E. coli could still be generally acknowledged as the most common cause of ASB.

Treatment of ASB was done using antibiotics selected from a list of drugs to which the isolated bacteria were sensitive. Ciprofloxacin and gentamycin were the most prescribed antibiotics for the treatment of ASB, as isolated bacteria were popularly sensitive to these drugs. In a separate study nitrofurantoin had high sensitivity whilst high resistance to ciprofloxacin was reported. ${ }^{[15]}$ It is therefore important to consider performing sensitivity test for all samples which significantly grow bacteria in ASB other than treat empirically.

This study could be the first one to give an insight into prevalence of ASB in Zimbabwe. The knowledge of the considerable burden of ASB among pregnant women in the country may be used to consider as priority inclusion of interventions and strategies to prevent the disease and or treat it during antenatal care. These strategies will help reduce cases of ASB complication and adverse outcomes associated with it in pregnancy.

\section{Conclusion}

Asymptomatic bacteriuria is a common disease in pregnancy and is great concern as it is associated with pregnancy complications and adverse birth outcomes. Prevalence of ASB was significant in this study. Screening and treatment of ASB could help reduce adverse birth outcomes. More prevalence studies are needed in Zimbabwe to have the real picture of the disease burden.

Conflicts of Interest: No conflicts declared.

\section{References}

1. Jain V, Das V, Agarwal A, Pandey A. Asymptomatic bacteriuria and obstetric outcome following treatment in early versus late pregnancy in north Indian women. Indian J Med Res 2013; 137:753-8.

2. Khan S, Rashmi, Singh P, Siddiqui Z, Bums ZS, Ansari M. Pregnancy-associated asymptomatic bacteriuria and drug resistance. J Taibah Univ Sci 2015;10:340-5.

3. Thakre SS, Dhakne SS, Thakre SB, Thakre AD, Ughade SM, Kale P. Can the Griess nitrite test and a urinary pus cell count of $\geq 5$ cells per microliter of urine in pregnant women be used for the screening or the early detection of urinary tract infections in India? J Clin Diagn Res 2012;6:1518-22.

4. Abdullahi HI, Thairu Y. Asymptomatic bacteriuria among pregnant women attending antenatal: evaluation of screening test. IOSR Journal of Pharmacy 2015;5(8):41-7.

5. Matuszkiwewicz-Rowinska J, Malyszko J, Wieliszko M. Urinary tract infections in pregnancy: old and new unresolved diagnostic and therapeutic problems. Arch Med Sci 2015;11: 67-77.

6. Smail FM, Vazquez JC. Antibiotics for asymptomatic bacteriuria in pregnancy. Cochrane Database of Syst Rev 2015;(8): CD000490.

7. Verma A, Vyas A, Shrimali L, Sharma M. Asymptomatic bacteriuria and antibacterial susceptibility during pregnancy. Int J Reprod Contracept Obstet Gynecol 2016;5:407-10.

8. Angelescu K, Nussbaumer-Streit B, Sieben W, Scheibler F, Gartlehner G. Benefits and harms of screening for and treatment of asymptomatic bacteriuria in pregnancy: a systematic review. BMC Pregnancy Childbirth 2016;16:336.

9. Smail F. Asymptomatic bacteriuria in pregnancy. Best Pract Res Clin Obstet Gynecol 2007;21:439-50.

10. Perera J, Randeniya C, Perera P, Gamhewage N, Jayalathaarachchi R. Asymptomatic bacteriuria in pregnancy: prevalence, risk factors and causative organisms. Sri Lankan Journal of Infectious Diseases 2012;1:42-6.

11. Musona-Rukweza J, Haruzivishe C, Gidiri MF, Nziramasanga P, Stray-Pedersen B. Asymptomatic bacteriuria in pregnancy: a concept analysis. Journal of Microbiology Research and Reviews 2017;4:1-11.

12. Manjula R, Kavya H, Kashinakunti, Solabannavar S, Dorle AS, Lalitha DH. Diagnostic accuracy of Griess test for asymptomatic bacteriuria in pregnancy. Br J Med Med Res 2016;11: $1-7$.

13. Radha S, Nambisan B, Prabhakaran NK, Jamal S. Prevalence and outcome of asymptomatic bacteriuria in early pregnancy. Int J Reprod Contracept Obstet Gynecol 2017;6:223-7.

14. Gilbert NM, O'Brien VP, Hultgren S, Macones G, Lewis WG, Lewis AL. Urinary tract infection as a preventable cause of pregnancy complications: opportunities, challenges, and a global call to action. Glob Adv Health Med 2013;2:59-69.

15. Mukherjee M, Koley S, Mukherjee, Basu S, Ghosh B, Chakraborty S. Phylogenetic background of E. coli isolated from asymptomatic pregnant women from Kolkata, India. J Infect Dev Ctries 2015;9:720-4. 
16. Ipe DS, Sundac L, Benjamin WH Jr, Moore KH, Ulett GC. Asymptomatic bacteriuria: prevalence rates of microorganisms, etiology of infection in different patient populations, and recent advances in molecular detection. FEMS Microbiol Lett 2013;346:1-10.

17. Musona-Rukweza J, Nziramasanga P, Gidiri MF, Haruzivishe CO, Stray-Pedersen. Effectiveness of Griess nitrite test on screening asymptomatic bacteriuria in pregnancy: a cross sectional study in Harare, Zimbabwe. Adv Microbiol 2017;5:1-9.

18. Grabe M, Bartoletti R, Bjerklund Johansen TE, Cai T, Çek M, Köves B, et al. Guidelines on urological infections. Arnheim: European Association of Urology; 2015. Accessed through: https://uroweb.org/wp-content/uploads/19-Urological- infections_LR2.pdf

19. Akinloye O, Ogbolu DO, Akinloye OM, Terry-Alli OA. Asymptomatic bacteriuria of pregnancy in Ibadan, Nigeria: a re-assessment. Br Biomed Sci 2006;63(3):109-12.

20. Ghafari M, Baigi V, Cheraghi Z, Doosti-Irani A. The prevalence of asymptomatic bacteriuria in Iranian pregnant women: a systematic review and meta-analysis. PLoS One 2016;11: e0158031.

21. Abdel-Aziz Elzayat M, Barnett-Vanes A, Dabour MF, Cheng F. Prevalence of undiagnosed asymptomatic bacteriuria and associated risk factors during pregnancy: a cross-sectional study at two tertiary centres in Cairo, Egypt. BMJ Open 2017;7:e013198.

22. Campbell-Brown M, McFadyen IR, Seal DV, Stephenson $\mathrm{ML}$. Is screening for bacteriuria in pregnancy worth while? $\mathrm{Br}$ Med J (Clin Res Ed) 1987;294:1579-82.

23. Sunday TS, Temitope AI, Adelowo AO. Asymptomatic bacteriuria in pregnancy in Osogbo with special reference to staphylococcus saprophyticus. Afr J Infect Dis 2009;3:36-43.

24. Mabeck CE. Significance of coagulase negative staphylococcal bacteriuria. Lancet 1969; 294(7631):1150-2.

25. Sujatha R, Nawani M. Prevalence of asymptomatic bacteriuria and its bacterial susceptibility pattern among pregnant women attending the antenatal clinic at Kanpur, India. J Clin Diagn Res 2014;8(4):1-3. 